\title{
Häufig verwendete Symbole
}

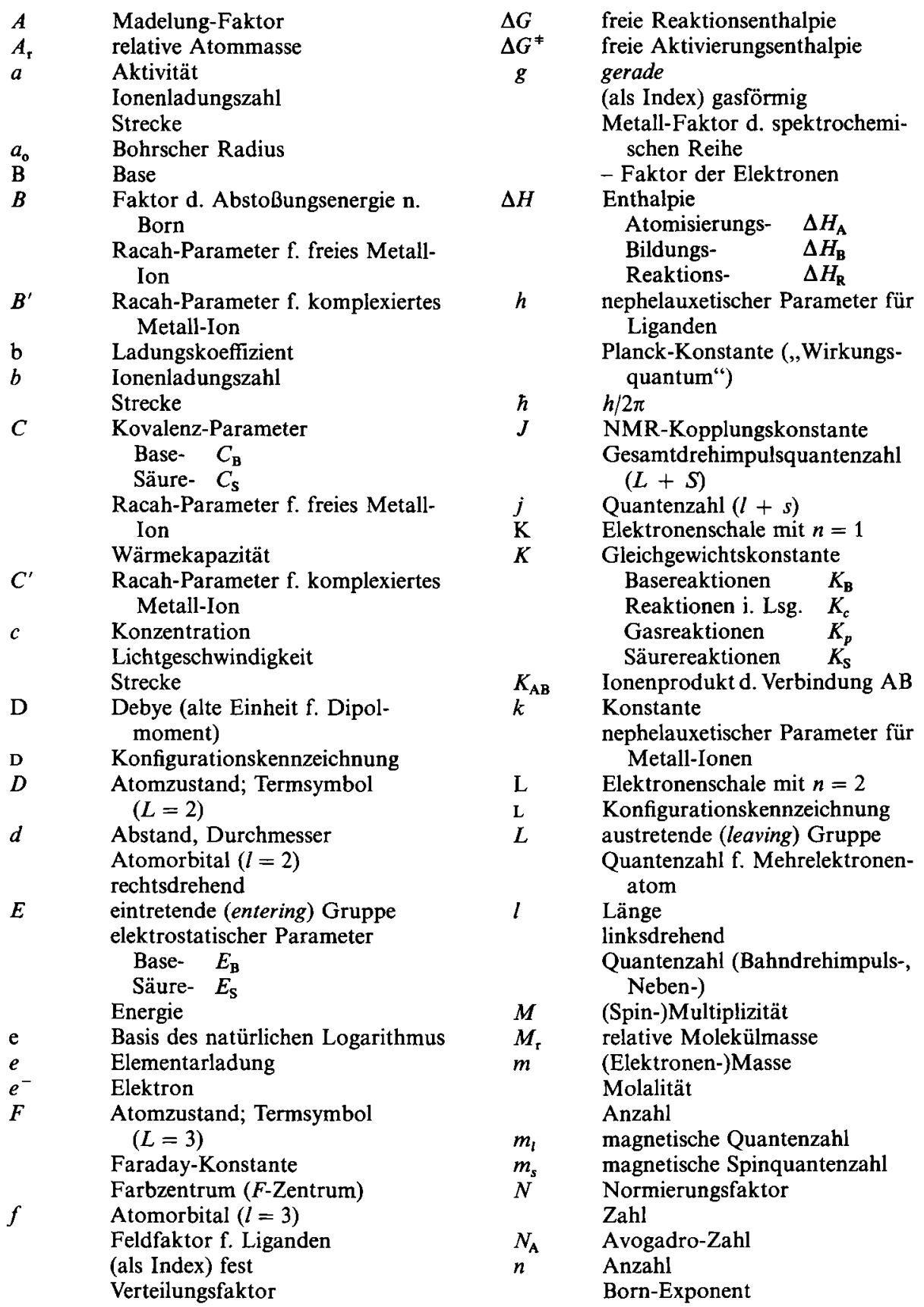

